\title{
NSAIDs: can the presence of infectious agent influence the choice of analgesic drug?
}

\author{
O. A. Podpletnya, O. V. Khomiak, I. P. Koshova \\ SE "Dnipropetrovsk Medical Academy of Ministry of Health of Ukraine", Dnipro
}

Purpose. Considering the significant prevalence of comorbid pathology there is a high probability of NSAID use in patients with concomitant infection. In view of this screening of antimicrobial properties of their main groups was conducted for the purpose of selecting the most promising ones for further in-depth study.

Materials and methods. The study of microorganisms' sensitivity was conducted using standard research methods - the method of "wells" and by determining the antibacterial properties of drugs, using tablets, based on the ability of the drug to diffuse into agar, used for sowing the test-culture. As the test cultures S. aureus, S. mutans, S. pyogenes, P. aeruginosa, E. Coli, isolated from patients who were treated in hospital were used. Predominant blocker of COX-1 (acetylsalicylic acid, ASA), nonselective blockers of COX-1 and COX-2 (ketorolac, diclofenac sodium, ibuprofen, mefenamic acid, dexketoprofen), predominant blockers of COX-2 (meloxicam and nimesulide), selective blockers of COX-2 (celecoxib), selective blockers of COX-3 (COX-1 in the brain) paracetamol and metamizole were tested.

Results. The studies found that most of the tested NSAIDs have antimicrobial activity. Leader drugs in expressiveness of antimicrobial effects are drugs that have sufficient COX-1 (3) - activity: ASA, diclofenac, dexketoprofen, metamizole and lesser extent - paracetamol. Tested NSAIDs showed the highest activity against gram-positive coccal flora, mostly affecting S. Pyogenes. Blockers of COX-3 paracetamol and metamizole, unlike other studied drugs, showed stronger antipseudomonal (both - moderate) and antistaphylococcal action (metamizole).

Conclusions. NSAIDs with antimicrobial activity can potentially increase the activity of antiinfectious therapy. At the same time, the antimicrobial activity of NSAIDs, theoretically, can promote microbial resistance because of existence of microorganisms in a medium with subthreshold concentrations of drugs with antimicrobial activity. Considering this, further clinical and pharmacological research of this problem has a great practical importance.

\section{НПЗП: чи може наявність інфекційного агента впмивати на вибір знеболювального препарату?}

\section{О. А. Подплетня, О. В. Хомяк, І. П. Кошова}

Мета роботи -у зв'язку із значною поширеністю коморбідної патології великою є ймовірність застосування НПЗП у хворих, що мають супутній інфекційний процес. 3 урахуванням цього здійснене скринінгове дослідження антимікробних властивостей основних груп цих препаратів із ціллю відбору найперспективніших із них для дальшого поглибленого вивчення.

Матеріали та методи. Чутливість МО вивчали з використанням стандартних методів дослідження: методу «колодязів» і методу визначення антибактеріальних властивостей препаратів за допомогою таблеток, що заснований на здатності лікарської речовини дифундувати в агар, на який висівали тест-культури. Як тест-культури використовували S. aureus, S. mutans, S. pyogenes, P. aeruginosa, E. coli, що виділені від хворих, які перебували на лікуванні у стаціонарі. Протестовані переважний блокатор ЦОГ-1 (ацетилсаліцилова кислота, АСК), неселективні блокатори ЦОГ-1 і ЦОГ-2 (кеторолак, диклофенак натрію, ібупрофен, мефенамінова кислота, декскетопрофен), переважні блокатори ЦОГ-2 (мелоксикам і німесулід), селективні блокатори ЦОГ-2 (целекоксиб), селективні блокатори ЦОГ-3 (ЦОГ-1 у мозку) парацетамол і метамізол.

Результати. Під час досліджень встановили, що більшість тестованих НПЗП має антимікробну активність. Препаратами-лідерами з виразності протимікробних ефектів є препарати, що мають достатню ЦОГ-1(3)-активність: АСК, диклофенак, декскетопрофрен, метамізол, меншою мірою - парацетамол. Найбільшу активність тестовані НПЗП проявляли щодо грампозитивної кокової флори, більшою мірою впливаючи на S. pyogenes. Блокатори ЦОГ-3 парацетамол і метамізол, на відміну від інших препаратів, що вивчалися нами, сильніше проявляли антисиньогнійну (обидва - помірну) та антистафрілококову дію (метамізол).

Висновки. НПЗП з антимікробною активністю потенційно можуть підвищувати активність протиінфекційної терапії. Водночас антимікробна активність НПЗП теоретично може сприяти розвитку резистентності мікроорганізмів унаслідок наявності останніх у середовищі з підпороговими концентраціями засобів із протимікробною активністю. 3 урахуванням цього велике практичне значення має здійснення дальших клініко-фрармакологічних досліджень проблеми.
Key words: NSAIDs, comorbidity, analgesics.

Pathologia 2017; 14 (2), 219-223 Dol: 10.14739/2310-1237. 2017.2.109671

E-mail: koshevaya.ip@ gmail.com
Кмючові слова: НПЗП, коморбінність, анальгетики.

Патомогія. - 2017. T. 14, № 2(40). C. $219-223$

\section{НПВС: может ми наличие инфекционного агента влиять на выбор обезболивающего препарата?}

\section{Е. А. Подплетняя, Е. В. Хомяк, И. П. Кошевая}

Цель работы - в связи со значительной распространенностью коморбидной патологии велика вероятность применения НПВС у больных, имеющих сопутствующий инфекционный процесс. С учетом этого проведено скрининговое исследо-

Ключевые слова: HПBC, коморбиАность, анальгетики.

Патология. - 2017. -

T. 14, № 2(40). C. 219-223 
вание антимикробных свойств основных групп этих препаратов с целью отбора наиболее перспективных из них для дальнейшего углубленного изучения.

Материалы и методы. Исследование чувствительности МО проводилось с использованием стандартных методов исследования - метода «колодцев» и метода определения антибактериальных свойств препаратов с помощью таблеток, основанного на способности лекарственного вещества диффундировать в агар, на который проводится высев тест-культуры. В качестве тест-культур использовали S. aureus, S. mutans, S. pyogenes, P. aeruginosa, E. coli, выделенные от больных, находившихся на лечении в стационаре. Протестированы преимущественный блокатор цОГ-1 (ацетилсалициловая кислота, АСК), неселективные блокаторы ЦОГ-1 и ЦОГ-2 (кеторолак, диклофенак натрия, ибупрофен, мефенаминовая кислота, декскетопрофен), преимущественные блокаторы ЦОГ-2 (мелоксикам и нимесулид), селективные блокаторы ЦОГ-2 (целекоксиб), селективные блокаторы ЦОГ-3 (ЦОГ-1 в мозге) парацетамол и метамизол.

Результаты. В ходе исследований установлено, что большинство тестируемых НПВС обладает антимикробной активностью. Препаратами-лидерами по выраженности противомикробных эффектов являются препараты, обладающие достаточной ЦОГ-1 (3)-активностью: АСК, диклофенак, декскетопрофен, метамизол, в меньшей степени -парацетамол. Наибольшую активность тестируемые НПВС проявляли в отношении грамположительной кокковой фроры, в большей степени - влияя на S. pyogenes. Блокаторы ЦОГ-3 парацетамол и метамизол, в отличие от других препаратов, изучаемых нами, сильнее проявляли антисинегнойную (оба - умеренную) и антистафилококковую активность (метамизол).

Выводы. НПВС с антимикробной активностью потенциально могут повышать активность противоинфекционной терапии. В то же время антимикробная активность НПВС теоретически может способствовать развитию резистентности микроорганизмов вследствие существования последних в среде с подпороговыми концентрациями средств с противомикробной активностью. С учетом этого большое практическое значение имеет проведение дальнейших клинико-фрармакологических исследований проблемы.

Non-steroidal anti-inflammatory drugs (NSAIDs) are known to be a large group of drugs widely used in clinical practice, daily, for more than thirty million people worldwide. Taking into account the high prevalence of comorbid pathology under the clinic condition, especially for the elderly, there is a high probability of their taking by patients with concomitant infectious process, taking anti-infectious drugs. Several possible interactions of NSAIDs with anti-infectious agents shall be considered at complex pathology of this kind: 1) the probability of change of therapeutic effect (increase or decrease) due to the direct effects of NSAIDs on the pathogenic flora; 2) the probability of effect of NSAIDs - increase or decrease of the effectiveness of anti-infectious drugs due to changes in the pharmacokinetic characteristics of the last; 3 ) the probability of the impact of NSAIDs on the development mechanisms of pathogens resistance; 4) the probability of mutual reinforcement of side effects of drugs when used in combinations.

The reference sources contain a number of conflicting data about the direct or indirect effect of NSAIDs upon infectious diseases. On the one hand, acceleration of progression of soft tissue infections of streptococcal etiology (group A) at the application of certain non-selective (ketorolac, ibuprofen and indomethacin), but not COX-2 selective NSAIDs and reduction of efficiency of etiotropic antibiotic therapy were found [1]. On the other hand, in vitro, sodium diclofenac was detected to show antibacterial activity against antibiotic-sensitive and antibiotic-resistant strains of microorganisms, including mycobacteria, associated by the authors with the violation of the DNA synthesis of sensitive flora [2], in addition, antimycobacterial properties of diclofenac have been confirmed in an experiment in vivo [3]. It is also known, that NSAIDs have direct membranotropic effects, due to which, it seems to us, they can have their own antimicrobial activity, by analogy with membranotropic antibiotics, and also modulate the action of antimicrobial agents (stimulate or weaken) [4]. Currently the systematized data about NSAIDs effect on various clinically relevant microorganisms are not available.
This thesis was aimed to conduct screening of antimicrobial properties of the major NSAIDs groups and selection of the most promising ones for further studies.

\section{Materials and methods}

Particular features of pharmacodynamics of drugs (selectivity with respect to different types of COX), as well as the clinical significance and frequency of drug usage according to main indications were taken into consideration at selecting NSAIDs for screening of antimicrobial properties. List of NSAIDs and nonnarcotic analgesic drugs (NAD) is provided in Table 1.

5 major clinical strains of microorganisms (MO) were used as testing cultures, i. e., S. aureus, S. mutans, $S$. pyogenes, $P$. aeruginosa, $E$. coli, isolated from patients treated in hospital. Selection of MO types was determined by the clinical relevance of the latter.

MO sensitivity study was conducted using the method of «wells» (agar diffusion method) and the method of determining the antibacterial properties of chemotherapeutic agents using the tablets, according to guidelines [5]. The method is based on the ability of the drug to diffuse into the agar, onto which the testing culture is plated.

Sterile Petri dishes were put on a strictly horizontal surface, to pour $20 \mathrm{ml}$ of $2 \%$ meat infusion agar $(\mathrm{pH}=7.2-7.4)$ in order to create an optimal thickness of a layer, equal to $4-5 \mathrm{~mm}$. $5 \%$ blood or serum agar was applied for microbial species that do not grow using meat infusion agar (Streptococcus). Dishes with a medium were dried in a thermostat before inoculation.

A thick layer of agar was inoculated with $0.1 \mathrm{ml}$ suspension of the tested $\mathrm{MO}$ and triturated with a spatula until uniform distribution of MO over the surface of the Petri dish. Then drill $(\mathrm{d}=6 \mathrm{~mm})$ was used to drill holes («wells») at equal distances from each other, to further fill them with the tested objects. Then the plates were placed to thermostat at $37^{\circ} \mathrm{C}$ horizontally, to form circular zones. Diameters of inhibition zones were measured in 24 hours. 
When determining the properties of antibacterial chemotherapeutics with the tablets, the latter were applied to the agar surface with the test bacteria. After incubation on the place of tablets application, the sterile zones were taken into account; criterion for evaluation was the delay zone of microflora growth: at level up to $10 \mathrm{~mm}$ or absence thereof the microorganisms are not sensitive to the drug; 11-15 $\mathrm{mm}$ zone shows low sensitivity and more than $15 \mathrm{~mm}$ zone refers to sensitive strains. Thus inhibition zones of $\mathrm{MO}$ from 5 to $10 \mathrm{~mm}$ indicated bacteriostatic effect; inhibition zones exceeding $10 \mathrm{~mm}$ indicated bactericidal action.

Statistical processing of the results was carried out with the use of the package of licensed applications Statistica (6.1, AGAR909E415822FA serial number). Type of parameters distribution was analyzed by Shapiro-Wilk test. Significant differences between the indices, taking into account the type of distribution were determined by Student's t-test. The threshold level of statistical significance of the results was $p<0.05$. Results are presented as $M \pm S D$.

The results of the study of NSAIDs and NNA antimicrobial properties are presented in Table 2.

Some NSAIDs were detected to have a significant antimicrobial activity. The most pronounced antimicrobial effects are manifested by ASA, diclofenac, dexketoprofen, paracetamol and metamizole ( $3-4$ sensitive pathogens). To a lesser extent, ketorolac, ibuprofen and COX-2 selective NSAIDs (nimesulide, meloxicam and celecoxib) have effect on 1-2 pathogens. There was no antimicrobial activity detected in mefenamic acid.

When comparing the effects of NSAIDs and NAD on individual pathogens, attention is drawn to the high sensitivity of the non-antimicrobial drugs of the beta-hemolytic streptococcus $S$. pyogenes. It reacted substantially to all the NSAIDs except mefenamic acid and paracetamol, and to a greater extent - to ibuprofen and ASA (zone of growth absence is $16.0 \pm 1.6 \mathrm{~mm}$ ); with other drugs the $\mathrm{MO}$ inhibition zones were about 12-14 mm (Fig. 1).

Another representative of Streptococcus, alpha-hemolytic streptococcus $S$. mutans, showed greater selectivity as for sensitivity to NSAIDs: the highest efficiency was shown by dexketoprofen (zone of growth absence is $20.0 \pm 1.7$ ), other drugs were significantly less effective: ASA, diclofenac, metamizole had inhibition zone of MO within 11-12 mm, inhibition zone of paracetamol was at the efficiency limit, i. e., $10 \mathrm{~mm}$.

The sensitivity of $S$. aureus was the highest to diclofenac and metamizole (inhibition zone is $29-31 \mathrm{~mm}$ ), much lower to ASA (15 mm) and at a low level - to ibuprofen and dexketoprofen (11-12 mm). Inhibition zone of this pathogen in paracetamol was at the efficiency limit, i.e., $10 \mathrm{~mm}$ (Fig. 2).

Gram-negative flora was significantly less sensitive to studied NSAIDs and NAD. E. coli showed complete resistance to drugs of NSAIDs and NAD, $P$. aeruginosa showed moderate sensitivity to paracetamol (zone $13.0 \pm 1.2)$ and weak sensitivity to ASA $(11.0 \pm 1.2)$ (Fig. 3).

The study of antimicrobial effect of NSAIDs on the strains of testing cultures, at cultivation using blood agar, detected hemolytic effect of varying intensity of some NSAIDs (ASA, ibuprofen, nimesulide, diclofenac, paracetamol) (Fig. 4), which may indicate the effect of NSAIDs on erythrocyte membranes.
Table 1. List of NSAIDs and NNAs used in the research

\begin{tabular}{lll}
\hline Group & International name & Trade name \\
\hline Predominant COX-1 blockers & Acetylsalicylic acid (ASA) & Aspirine \\
Nonselective COX-1 and COX-2 blockers & Ketorolac & Ketorol \\
& & Ketanov \\
& Ibuprofen & Nurofen \\
& Diclofenac sodium & Voltaren \\
& & Dicloberl \\
& Dexketoprofen & Dexalgin \\
Predominant COX-2 blockers & Mefenamic acid & Mefenamic acid \\
& Nimesulid & Nimesil \\
Selective COX-2 blockers & Meloxicam & Movalis \\
Selective COX-3 blockers & Celecoxibe & Celebrex \\
(COX-1 in the brain) & Paracetamol & Panadol \\
& & Efferalgan \\
& Metamizole & Analgin \\
\hline
\end{tabular}

Table 2. Indicators of MO growth delay at testing NSAIDs and NNA

\begin{tabular}{|c|c|c|c|c|c|c|}
\hline \multicolumn{7}{|c|}{$\begin{array}{l}\text { Growth delay zones of test-strains, } \mathrm{mm} \\
(\mathrm{M} \pm \mathrm{SD}, \mathrm{n}=6)\end{array}$} \\
\hline № & Drug name & S. aureus & S. mutans & S. pyogenes & E. coli & $P$. aeruginosa \\
\hline 1 & ASA & $15,0 \pm 1,2$ & $12,0 \pm 1,4$ & $16,0 \pm 1,6$ & $8,0 \pm 0,7$ & $11,0 \pm 1,2$ \\
\hline 2 & Ketorolac & 0 & $6,5 \pm 0,6$ & $13,5 \pm 1,2$ & 0 & 0 \\
\hline 3 & Ibuprofen & $11,0 \pm 1,0$ & $9,0 \pm 1,1$ & $16,0 \pm 1,7$ & 0 & 0 \\
\hline 4 & Diclofenac sodium & $29,0 \pm 1,7$ & $11,0 \pm 1,0$ & $12,0 \pm 1,0$ & $4,0 \pm 0,6$ & 0 \\
\hline 5 & Dexketoprofen & $12,0 \pm 0,9$ & $20,0 \pm 1,7$ & $13,0 \pm 1,0$ & 0 & 0 \\
\hline 6 & Mefenamic acid & 0 & 0 & 0 & 0 & 0 \\
\hline 7 & Nimesulid & 0 & 0 & $13,0 \pm 1,1$ & 0 & 0 \\
\hline 8 & Meloxicam & $4,0 \pm 0,1$ & $7,0 \pm 0,9$ & $13,0 \pm 1,1$ & 0 & 0 \\
\hline 9 & Celecoxibe & $6,0 \pm 0,4$ & 0 & $12,0 \pm 1,1$ & 0 & 0 \\
\hline 10 & Paracetamol & $10,0 \pm 1,1$ & $10,0 \pm 1,2$ & $8,0 \pm 0,9$ & $3,0 \pm 0,4$ & $13,0 \pm 1,2$ \\
\hline 11 & Metamizole & $31,0 \pm 1,9$ & $11,0 \pm 1,2$ & $14,0 \pm 1,2$ & 0 & 0 \\
\hline
\end{tabular}

To certain extent our findings explain the data of available reference sources related to this subject, or correlate with it. Thus, interesting clinical data concerning the positive effects of preferential blocker of COX-1 acetylsalicylic acid (ASA) are given in the study of Low-Dose Acetylsalicylic Acid Treatment and Impact on Short-Term Mortality in Staphylococcus aureus Bloodstream Infection, carried out by M. Osthoff, J. A. Sidler, B. Lakatos in 2016 [6], showing that patients with staphylomycosis (excluding sepsis caused by $E$. coli) had lower mortality risks at receipt of ASA low-dose $(12.1 \%$ vs $27.4 \%$, p < 0.001$)$. There was also the decrease detected in cytotoxicity of $S$. aureus ratio concerning bone tissue and reduction of the risk of osteomyelitis at testing of salicylic acid derivative, i. e., diflunisal; it is associated with decreased synthesis of virulence factors of staphylococci due to effect on their accessory gene regulator (agr) [7].

Data inreference sources are insufficient for ibuprofen and ketorolac: controlled studies [1] detected acceleration of the progression of the soft tissue infections of streptococcal etiology (group A) at their application, as well as reduction of the effectiveness of etiotropic antibiotic therapy. Within our study ketorolac and ibuprofen showed no antimicrobial activity against $S$. mutans (the latter, according to our data, in general, was less sensitive to the inhibitory effects of NSAIDs), but were effective (more pronounced for ibuprofen) against $S$. pyogenes, 


\section{Оригінальні АосліАження}
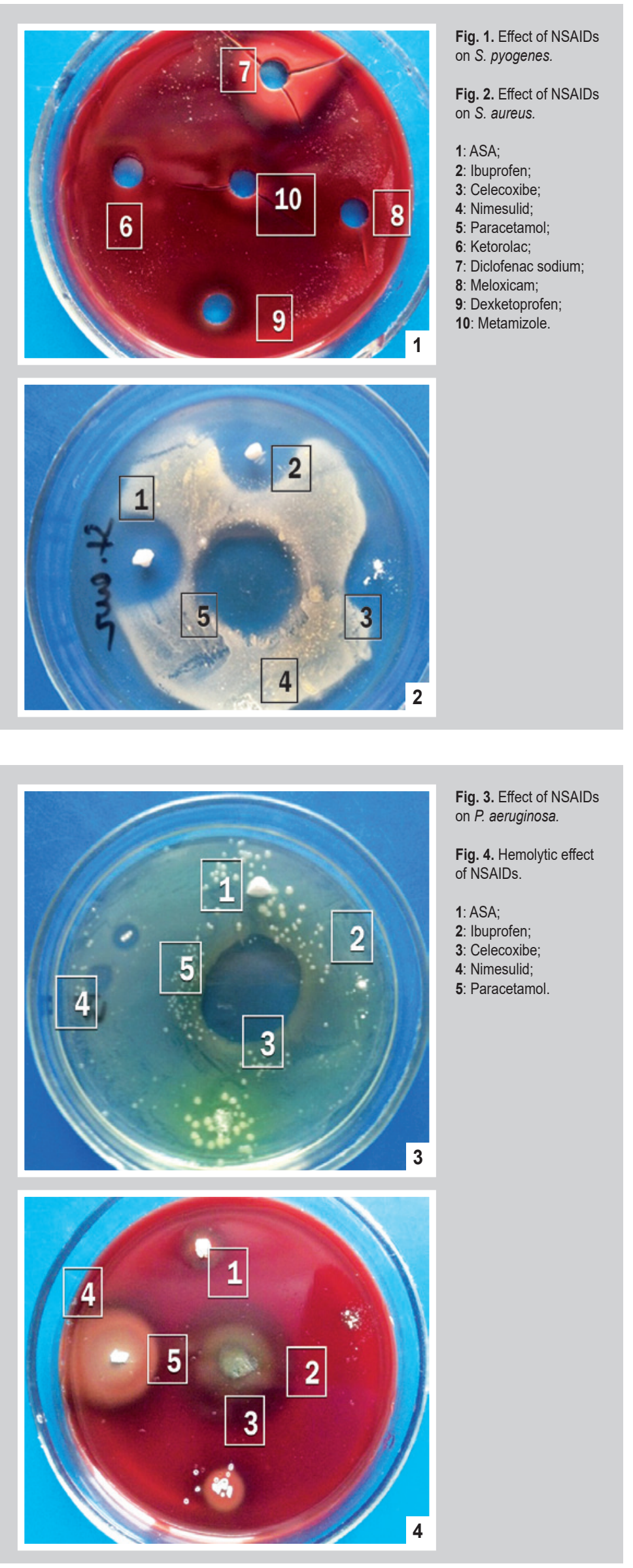

which is known to have a high sensitivity to antimicrobial agents of different groups and slowly develop resistance to them.

According to the reference sources sodium diclofenac showed antibacterial activity against antibiotic-sensitive and antibiotic-resistant strains of listeria and mycobacteria, explained with impaired DNA synthesis of sensitive flora [2]. Use of 30-50 mg/20 g diclofenac for mice reliably protected them from infection caused by gram-negative Salmonella typhimurium [8]; under conditions of our experiment it had practically no effect on gram-negative flora.

We found no data about the presence of the antimicrobial effect of ketoprofen and its dextrarotary isomer dexketoprofen on gram-positive cocci (as shown in our experiments), though there is available information about the use of ketoprofen in addition to enrofloxacin for intratracheal infection of pigs with gram-negative Haemophilus parasuis, while NSAIDs significantly improved vital signs of animals compared to the group receiving fluoroquinolone only [9].

No data about the direct impact of selective COX-2 blockers on gram-positive pathogenic flora are found, but there is an evidence of potentiating effect of celecoxib on sensitivity of S.aureus to antibiotics through increasing of SIRT1 protein regulatory level in macrophages [10] and through inhibiting efflux of antibiotics from a microbial cell [11].

In contrast to other studied drugs, COX-3 blockers, i. e., paracetamol and metamizole, showed stronger pseudomonas (both-moderate) and antistaphylococcal effect (metamizole).

The more pronounced overall antimicrobial activity of nonselective anti-COX drugs is probably due to the fact that one of the NSAIDs effect mechanisms on the development of $\mathrm{MO}$ resistance may be an impact on the synthesis of prostaglandin E2 (PGE2), as PGE2 is shown to be the stimulation factor of staphylococci resistance development [12].

Treatment of comorbidity shall also consider that NSAIDs may mask symptoms of infection process, lowering body temperature, which can lead to an incorrect evaluation of the efficacy of anti-infectious effect at their combined use.

\section{Conclusions}

1. The studies revealed the majority of the tested NSAIDs to have an antimicrobial activity.

2. Leader-drugs of antimicrobial effects are preparations with sufficient COX-1(3)-activity: ASA, diclofenac, dexketoprofen, metamizole, and paracetamol to a lesser extent.

3. Tested NSAIDs had the greatest activity against gram-positive cocci flora, mostly affecting $S$. Pyogenes.

4. Significance of antimicrobial activity of NSAIDs may be evaluated as a factor potentially enhancing the activity of anti-infectious therapy.

5. Antimicrobial activity of NSAIDs can theoretically contribute to the development of MO resistance due to the existence of the latter in a medium with subthreshold concentrations of agents with antimicrobial 
activity. From this perspective, further clinical and pharmacological studies of the problem are of great practical importance.

\section{References}

[1] Bryant, A. E., Bayer, C. R., Aldape, M. J., \& Stevens, D. L. (2015). The roles of injury and nonsteroidal anti-inflammatory drugs in the development and outcomes of severe group A streptococcal soft tissue infections. Curr Opin Infect Dis, 28(3), 231-239. doi: 10.1097/ QC0.0000000000000160.

[2] Mazumdar, K., Mazumdar Dastidar, S. G., Park, J. H., \& Dutta, N. K (2009). The anti-inflammatory non-antibiotic helper compound diclofenac: an antibacterial drug target. Eur J Clin Microbiol Infect Dis, 28(8), 881-891. doi: 10.1007/s10096-009-0739-z.

[3] Dutta, N. K., Mazumdar, K., Dastidar, S. G., \& Park, J. H. (2007). Activity of diclofenac used alone and in combination with streptomycin against Mycobacterium tuberculosis in mice. Int J Antimicrob Agents, 30(4), 336-340. doi: 10.1016/j.jjantimicag.2007.04.016.

[4] Habrieva, R. U. (2005). Rukovodstvo po e'ksperimental'nomu (doklinicheskomu) izucheniyu novykh farmakologicheskikh veshchestv [Manual on experimental (pre-clinical) study of the new pharmacological substances]. Moscow. [in Russian].

[5] Nunes, C., Brezesinski, G., Pereira-Leite, C., Lima, J. L., Reis, S., \& Lúcio, M. (2011). NSAIDs interactions with membranes: a biophysical approach. American Chemical Society, 27(17), 10847-10858. doi: $10.1021 / \mathrm{la} 201600 y$.

[6] Osthoff, M., Sidler, J. A., Lakatos, B., Frei, R., Dangel, M., Weisser, M., et al. (2016). Low-Dose Acetylsalicylic Acid Treatment and Impact on Short-Term Mortality in Staphylococcus aureus Bloodstream Infection: A Propensity Score-Matched Cohort Study. Crit Care Med, 44(4), 773-781. doi: 10.1097/CCM.0000000000001554.

[7] Hendrixa, A. S., Spoonmore, T. J., Wilde, A. D., Putnama, N. E Hammerc, N. D., Snydera, D. J., et al. (2016). Repurposing the Nonsteroidal Anti-inflammatory Drug Diflunisal as an Osteoprotective Antivirulence Therapy for Staphylococcus aureus Osteomyelitis. Antimicrob Agents Chemother, 22, 60(9), 5322-5330. doi: 10.1128/AAC. 00834-16.

[8] Dastidar, S. G., Ganguly, K., Chaudhuri, K., \& Chakrabarty, A. N. (2000). The anti-bacterial action of diclofenac shown by inhibition of DNA synthesis. Int J Antimicrob Agents, 14(3), 249-251. doi: https:// doi.org/10.1016/S0924-8579(99)00159-4.

[9] Viehmann, M., Postiasi, S., Balka, G., Spergser, J., Palzer, A., Hennig-Pauka, I., et al. (2013). Evaluation of the efficacy of a combination therapy of an antibiotic and a NSAID following an experimental Haemophilus parasuis infection in nursery piglet. Tierarztl Prax Ausg G Grosstiere Nutztiere, 41(4), 225-232.

[10] Annamanedi, M., \& Kalle, A. M. (2014). Celecoxib sensitizes Staphylococcus aureus to antibiotics in macrophages by modulating SIRT1. PLOS One, 9(6), e99285. doi: 11.1371/journal.pone.0099285.

[11] Arunasree, M. K., \& Arshad, Rizvi. (2011). Inhibition of Bacterial Multidrug Resistance by Celecoxib, a Cyclooxygenase-2 Inhibitor. Antimicrob Agents Chemother, 55(1), 439-442. doi: 10.1128/AAC. 00735-10.

[12] Krause, J., Geginat, G., \& Tammer, I. (2015). Prostaglandin E2 from Candida albicans Stimulates the Growth of Staphylococcus aureus in Mixed Biofilms. PLoS One, 10(8), e0135404. doi: 10.1371/journal. pone. 0135404 .

\section{Information about authors:}

Podpletnya O. A., DSc, Professor, Head of the Department of General and Clinical Pharmacy, SE "Dnipropetrovsk Medical Academy of Ministry of Health of Ukraine”, Dnipro.

Khomiak O. V., MD, PhD, Lecturer of the Department of Pharmacology and Clinical Pharmacology, SE “Dnipropetrovsk Medical Academy of Ministry of Health of Ukraine", Dnipro. Koshova I. P., MD, PhD, Associate Professor of the Department of General and Clinical Pharmacy, SE "Dnipropetrovsk Medical Academy of Ministry of Health of Ukraine”, Dnipro.

\section{Відомості про авторів:}

Подплетня 0. А., А-р фарм. наук, професор, зав. каф. загальної та киінічної фармації, АЗ "Аніпропетровська медична академія м03 України", м. Аніпро.

Хомяк О. В., канА. меА. наук, викладач каф. фармакології та клінічної фармакології, А3 "Аніпропетровська медична академія М03 України", м. Аніпро.
Кошова І. П., канА. меА. наук, Аоцент каф. загальної та клінічної фармації, АЗ "Аніпропетровська медична академія м03 України", м. Аніпро.

\section{Сведения об авторах:}

Подплетняя Е. А., А-р фарм. наук, профессор, зав. каф. общей и киинической фармации, ГУ "Анепропетровская меАицинская академия МЗ Украины", г. Анипро.

Хомяк Е. В., канА. меА. наук, преподаватель каф. фармакологии и клинической фармакологии, ГУ “Анепропетровская медицинская академия МЗ Украины", г. Анипро.

Кошевая И. П., канА. меА. наук, Аоцент каф. общей и клинической фармации, ГУ "Анепропетровская медицинская академия МЗ Украины", г. Анипро.

Конфмікт інтересів: віАсутній.

Conflicts of Interest: authors have no conflict of interest to declare.

Надійшло Ао редакції / Received: 29.05.2017

Після Аоопрацювання / Revised: 07.06.2017

Прийнято АО Аруку / Accepted: 12.06.2017 